\title{
STYLISTIC PECULIARITIES OF REPRESENTATION OF POLITICAL PHENOMENA IN BRITISH NEWSPAPERS
}

\author{
Ganna Prihodko \\ DSc, Professor, Zaporizhzhia National University, Ukraine \\ e-mail: anna.prikhodko.55@gmail.com,orcid.org/0000-0001-6220-5333 \\ Ivan Matsehora \\ Ph.D., Zaporizhzhia National University, Ukraine \\ e-mail: ivanmatsehora212@gmail.com,orcid.org/0000-0003-0928-0689
}

Andrii Galaidin

Ph.D. student, Polonia University in Czestochowa, Interdisciplinary Faculty, Poland e-mail: a.galaidin@ap.edu.pl,orcid.org/0000-0002-5236-1495

\section{Summary}

The presented paper highlights the results of a study of the usage of different expressive means and stylistic devices for the description of Brexit as a political phenomenon in English newspaper texts. Our analysis has proved that a political discourse proliferates with the language means, which clearly realize opposition FOR - AGAINST Brexit. It has been proved that stylistic means employed in the media are determined by the conditions of communication. If the desire of the speaker is to rouse the audience and to keep it in suspense, he will use various tropes and figures of speech. Furthermore, stylistic means are closely interwoven and mutually complementary thus building up an intricate pattern. It is stressed that the sign of evaluation in the media may be conditioned by various sociocultural factors, among which are the specifics of the sociocultural space, type of publication, genre specificity of the text, individual features of communicants' worldview. Accounting for these factors, contributes not only to a deep study of the stylistic phenomena, but also to effective communication and the creation of balanced journalistic texts, which, in its turn, will determine information and psychological comfort in society.

Keywords: Brexit, sociocultural, expressive means, stylistic devices, media, worldview.

\section{DOI https://doi.org/10.23856/4315}

\section{Introduction}

The role of media is very important in a modern society. At present with the introduction of Internet-services, even a common man is being exposed to international knowledge. There is no doubt that media is becoming more and more essential in our life (Happer \& Philo, 2013: 321-336; Vivian, 2012; Wimmer \& Dominick, 2013). Society is influenced by media in different ways. It is the media for the masses that helps them to receive information about a lot of things and also to form views and make conclusions regarding various issues. It is the media, which keeps the people updated and informed them about current affairs and the business world. Thus, mass media can be considered tools for the transfer of information, concepts, and ideas to the readers, listeners, or the viewers.

It is common knowledge that the most widespread platforms for mass media are newspapers, magazines, radio, television, and the Internet. The newspaper enlarges the general knowledge of the people (Manovich, 2001). Newspapers are considered to be a source of information, 
which is highly genuine and successful in the providing of timely information to the audience. Another attractive quality of the newspaper is that it presents wide-ranging information, which is not available on any other resource of media.

It must be noted that newspapers have been scrupulously studied from different angles: structure and composition (Wodak \& Busch, 2004: 105-123), typology (Kazak, 2014: 65-76), concepts and categories (Dobrosklonskaya, 2008; Volodina, 2003), and language means (Konyushkevich, 2016: 93-104).

In this respect the role of context and functioning of stylistic means in the creation, realization, and interpretation of different social phenomena in media texts should be mentioned.

The subject of the discussion is the study of stylistic means of expression of phenomenon Brexit in British newspaper texts. The aim of this paper is to establish the role of different stylistic means in the description of Brexit as a political phenomenon in British newspapers.

\section{Data and methodology}

The methodology applied in the study is based on the fundamental points of the theory of expressive means and stylistic devices and the theory of Context, which presents fundamental notions for linguistic analysis. This research involves a variety of methods. A descriptive method, by which we mean a set of research techniques that allow one to move from particular observations to generalizations and conclusions is widely used; contextual and presuppositional analysis, allowing to detect the influence of the role structure of the communication situation, social factors on the communicative semantics, and functional features of utterances with stylistic means (van Dijk, 1977: 19; Kachru, 2008; Kecskes, 2013).

The material under analysis was a selection of approximately 400 fragments of texts from tthe English media portals (www.reuters.com, www.theguardian.com). The criterion of the selection was the existence of expressive means and stylistic devices in the fragments.

\section{Historical and social context of Brexit}

Brexit means the withdrawal of the United Kingdom from the European Union and the political process connected with it (Brexit, 2017). It represented and characterized the peak of many fundamental narratives within the United Kingdom that ended in a referendum and the exit from the European Union.

The process of UK withdrawal from the European Union, called Brexit (from fusion of the English words Britain and exit), is one of the most highlighted and discussed events over the past few years. We are witnessing the formation of a new stage of international relations between the UK and other countries of Europe. No wonder the analytics and experts in various fields of economic, socio-political, and cultural life make their predictions on how Brexit will affect the lives of inhabitants of the UK, Europe, and the rest of the world and how this process changes the role of the United Kingdom on the world arena.

The Leave campaigns were aimed at the identification of Britishness as individuality and in regaining independence from the European Union. They appealed to the public through pathos and outline the European Union negatively and unconstructively. In stark contrast to the Leave campaign, the Remain campaign, led by Prime Minister David Cameron, sought to unify a divided conservative party as well as to convince the British people that remaining in the European Union was the right move for Britain (Shing, 2016). 
The study of the socio-historic narrative is an interesting topic as the United Kingdom has had an ambivalent relationship with the European Union. The Leave campaign was able to confirm victory in the referendum due to their employment and appellation to sorrow in the voters. They were able to do this by gaining the public opinion of the European Union and related issues of dissatisfaction and solely frame the European Union as the performer of their problems. This was based on an ambivalent historical relationship with the European Union and a feeling of national identity that was controlled by the Leave sides to persuade the voters to break free of the binds of the European Union (Brexit, 2017).

The Leave campaign focused on reactivating the underlying cultural narrative of Euroscepticism, which has been reinforced in the United Kingdom through decades of political rhetoric and public discourse. They activated emotions within the voters by appealing to national pride as well as the danger of losing their independence and used rhetoric, which consisted of "native vs foreign" as scare tactics when addressing the community (Veltri et al., 2019: 18-31).

They posed a complicated problem to the public asking them whether they wanted Britain to have its own set of laws and control over the country and if they did not act in response by voting Leave, then they were considered to be enemies of Britain. Leave outlined the European Union as a whipping boy for the difficulties of the country because of immigration and lack of sovereignty and presented exit from the European Union as the solution to the crisis (Shing, 2016).

The above mentioned confirms the urgent necessity to study the phenomenon of Brexit in broad perspective, because such researches fully reveal not only the social but also the linguistic significance of this notion (Morozova, 2017: 250-256).

\section{Specific features of the stylistic means of depiction of Brexit in the British newspapers}

This part presents a general overview of the stylistic means of illustration of Brexit as described in British newspapers.

It should be noted that the British media traditionally elucidates events in the most objective manner. However, with regard to events unfolding in their own country, having a national scale, it is difficult to talk about objectivity, as such. On the one hand, the media makes every effort to provide reliable, objective information, and on the other hand, it transmits certain values. Thus, the information presented in the media is rarely neutral; it always carries a definite appraisal, which is expressed by the usage of various expressive means and stylistic devices.

The study of the stylistic peculiarities of description of Brexit is carried out on the traditionally distinguished quality press in Britain: "The Guardian.com" and "Reuters.com".

The reason for choosing "The Guardian.com" is its left-centre political and value orientation. Its readers are left-thinking UK citizens who have a negative attitude towards Brexit. It is therefore interesting to interpret the political situation on the part of this media after the UK's withdrawal from the European Union.

The motive for choosing "Reuters news agency" is its conservative right-wing political and value orientation. Although the Agency endorses the values of objectivity, it is known that its management and editors have a right-wing perception and evaluation of events. We assume that Reuters has never openly criticized the UK's withdrawal from the European Union. It retains the objectivity status of a news agency. That is why the analysis and interpretation of the UK's withdrawal with the help of different stylistic means will be interesting. 
According to many researchers (Hood, 2010; Maliarchuk-Proshina, 2015: 89-94), one of the main features of the language of the media is the presence of social appraisal. This is due to the pragmatic function of media texts, designed primarily to influence the addressees. The language of journalism reflects the urgent problems of the life of modern society with the help of a wide range of tools. The active use of a range of means in the language of the media is determined by various factors, including the removal of censorship and the search for new expressive means for newspaper texts.

The vivid characteristic of media texts determines the existence of special language means for the implementation of the society's attitude to Brexit. Such means, providing the pragmatic effect of a journalistic text, are manifested at the lexical and syntactic levels.

The most frequently used tropes in the British media are to be mentioned. In analysed English newspapers the epithet is often used:

(1) "The prime minister toasted the moment with English Sparkling wine in Downing Street, which was illuminated by a red and blue light show, as were government departments along Whitehall, and parliament square was decked with union flags for the historic day; but Big Ben did not bong, contrary to the hopes of ardent Brexiters". ("Boris Johnson promises Brexit will lead to national revival"). January 31, 2020. (https://www.theguardian.com/politics/2020/jan/31/boris-johnson-promises-brexit-will-lead-to-national-revival)

The adjective ardent, which performs the function of the epithet, reveals the ironical characterization of opponents of the withdrawal from the European Union. Moreover, negative attitude to opponents is emphasized by the derivative Brexiter from the neologism Brexit that has a negative connotation.

Often epithets are used to portray positive emotional descriptions of a certain object or event as in the following fragment:

(2) "Happy Brexit Day! ... At last the day comes when we break free. A massive victory for the people against the establishment...11 pm tonight marks the point of no return. Once we Leave, we will never rejoin the European Union. Time to celebrate". ("Joy and sadness: How the world is reacting on Brexit Day"). January 31, 2020. (https://www.reuters.com/article/us-britain-eu-reaction/joy-and-sadness-how-the-world-is-reacting-on-brexit-day-idUSKBN1ZU0YZ)

Hopefulness and delight about leaving the European Union are emphasized by epithets with the positive meanings happy and massive. In addition, an exclamatory nominative sentence Happy Brexit Day! is also involved in the creation of a positive nature of the statement.

The simile, which acts as a means of likening one object to another according to a certain attribute in order to establish resemblances or differences between them, is also quite frequently met in British newspapers:

(3) "Boris Johnson now faced a challenge of colossal dimensions: to recover the unity of a country divided between those who see Brexit as a liberation, and those who consider it a tragedy and a historical error". ("Britain is retrenched on its island': Europe's papers react to Brexit day"). February 1, 2020. (https://www.theguardian.com/politics/2020/feb/01/britainretrenched-island-europe-papers-react-to-brexit-day)

Here we observe the functioning of similes, which demonstrate the contradictory approaches to Brexit.

This trope is used to express feelings of anxiety and apprehension about the future of Europe:

(4) "Now the future of the Eurostar is uncertain. The service was seen as a symbol of a Europe without borders, but it has failed to meet expectations - especially in terms of 
passenger numbers". ("Last train to Europe: All aboard the Eurostar as Britain bids goodbye"). February 1, 2020. (https://www.reuters.com/article/uk-britain-eu-tunnel/last-train-to-europeall-aboard-the-eurostar-as-britain-bids-goodbye-idUSKBN1ZU36U)

The most important technique in journalism is a metaphor, the essence of which is to transfer the name and properties of one object to another according to the principle of their similarity.

Based on the analysis of the articles, we can conclude that the particular expressiveness, accuracy, and emotionality are given by sustained metaphors, in which the metaphorical image is realized in several phrases or sentences:

(5) "Nearly four years after the Brexit vote, Britain has left the European Union, closing a rancorous chapter in the country's history and beginning another viewed by some with optimism and others with dismay". ("Boris Johnson promises Brexit will lead to national revival"). January 31, 2020. (https://www.theguardian.com/politics/2020/jan/31/boris-johnson-promisesbrexit-will-lead-to-national-revival)

In this statement metaphor is created due to the implicit comparison of exit with hostile enemy. The negative meaning is strengthened by the antithesis by some with optimism and others with dismay, which conveys the people's stance to Brexit.

It goes without saying that metaphors also belong to productive means of expressing the situation of the split of British society into "friends" and "strangers" in analytical articles. The actualization of the conceptual metaphor (FAMILY=DIVORCE) is significant. The authors of Brexit publications regularly refer to such images as family disorder or divorce:

(6) "So on "Brexit Day", some will celebrate and some will weep - but many Britons will do neither. Many are simply happy that more than three years of tortuous political wrangling over the divorce are over". ("Brexit day: Britain quits EU, steps into transition twilight zone"). January 31, 2020. (https://www.reuters.com/article/uk-britain-eu-union/brexit-daybritain-quits-eu-steps-into-transition-twilight-zone-idUSKBN1ZU003)

The parallel drawn between a family facing divorce and the situation, in which Great Britain exit from the European Union, is intended to emphasize such implicit meanings as the existence of close relations between the European Union and the United Kingdom and the pain of their separation, as well as the inevitability of terrible consequences.

Thus, analysis of newspaper articles on Brexit reveals a number of stylistic tools that are used in British political discourse during the period of aggravation of social relations.

The analysis of British newspapers shows that as far as the stylistic syntax is concerned the most frequently met are: parallel constructions, inversion, enumeration, rhetoric questions, and antithesis.

Parallel constructions may be viewed as a purely syntactical type of repetition for here we deal with the reiteration of the structure of several successive sentences (clauses), and not always of their lexical "flesh" (Markhasev \& Zajtseva 2010: 25):

(7) "In Parliament Square, site of hoarse slanging matches for the past four years, the crowds on both sides were thinner on Friday night, at least before the Farage rally got going. The leavers were beaming, proud in their sweatshirts bearing the slogan: Job Done. They believe spring is coming. The remainers were wrapped up against the cold, braced against a January night, which, to them, felt like the bleakest midwinter". ("That was Brexit: The mad energy of A Midsummer Night's Dream, but lasting three and a half years"). January 31, 2020. (https://www.theguardian.com/commentisfree/2020/jan/31/brexit-midsummer-nights-dream-politicians)

Certainly, parallel constructions illustrate the different position of the British to Brexit. The usage of antithesis (the leavers, the remainers) makes it more vivid. 
Linguists also draw attention to such a stylistic figure of speech as inversion, typical of the media, which is known as emphatic construction. Inversion is aimed at attaching logical stress and additional emotional colouring to the surface meaning of the utterance:

(8) "In our diplomacy, in our fight against climate change, in our campaigns for human rights or female education or free trade we will rediscover muscles that we have not used for decades. The power of independent thought and action," he said. " "Boris Johnson promises Brexit will lead to national revival"). January 31, 2020. (https://www.theguardian.com/politics/2020/jan/31/boris-johnson-promises-brexit-will-lead-to-national-revival)

Inversion presupposes a reply with more certainty than the normative sentence. It is the assuredness of the speaker of the positivity concerning the exit from the European Union that constitutes additional information, which is brought into the statement by the inverted word order. Enumeration and nominative sentence provide the intensification of the speaker's belief in the appropriateness of his actions.

No less common is the use of a rhetorical question. This figure of speech stands out among narrative sentences both intonationally and structurally, introducing an element of surprise into the speech and thereby enhancing the expressiveness of the utterance:

(9) "Reflecting on the lessons of Brexit, European Commission President von der Leyen told broadcaster ARD: "We must stand up for Europe, otherwise at some point we won't have it any more". "Europe must deliver on the biggest questions - that's what we need the European level for," she added. "How will we address climate change? That is the 'European Green Deal' issue. How will we deal with digitalisation? I want us to have a concept for migration that is sustainable, effective but also human". ("Now EU must deliver, Commission chief says on Brexit day"). January 31, 2020. (https:/www.reuters.com/article/us-britain-eu-vonderleyen/now-eu-must-deliver-commission-chief-says-on-brexit-dayidUSKBN1ZU2V3)

Rhetorical questions express here anxiety and apprehension regarding the future of Europe. The change of intonation breaks the monotony of the intonation pattern and revives the attention of the listeners.

\section{Conclusions}

The results of this study show that expressive means and stylistic devices as a sociocultural attribute of a journalistic text turn out to be a multifaceted category.

Analysis of publications on the Brexit referendum reveals a number of language tools that are used in English newspaper texts within the period of exacerbated social relations and differences. In general, it can be concluded that a political discourse abounds with language means that explicitly realize opposition FOR - AGAINST Brexit.

The examination of stylistic means employed in Slovak and English media texts is determined by the conditions of communication. If the desire of the author is to rouse the audience and to keep it in suspense, he will use special tropes and figures of speech. The most frequently met are: epithets, similes, metaphors, parallel constructions, inversion, enumeration, rhetoric questions, and antithesis. Furthermore, stylistic means are closely interwoven and mutually complementary thus building up an intricate pattern.

It must be noted that the function of these stylistic means in the depiction of Brexit is very significant. In British media these stylistic means demonstrate the ambivalent attitude of the British towards Brexit, which is primarily conditioned by the political orientation of the analysed newspapers. 
As a concluding remark, further research connected with the stylistic means of description of other political and social phenomena would have great potential.

\section{References}

Brexit. (2017). Available at: http://www.investopedia.com/terms/b/brexit.asp Dobrosklonskaya, T. G. (2008). Medialingvistika: Sistemnyj podkhod k izucheniyu yazyka SMI: Sovremennaya anglijskaya mediarech' [Medialinguistics: A systematic approach to the study of the language of the media: Modern English media]. Moscow: Flinta. [in Russian]

Happer, C., Philo, G. (2013). The role of the media in the construction of public belief and social change. Journal of social and political psychology, 1 (1), 321-336.

Hood, S. (2010). Appraising research: Evaluation in academic writing. London: Palgrave Macmillan.

Kachru, Y. (2008). Cultures, contexts, and world Englishes. New York-London: Routledge.

Kazak, M. Yu. (2014). Sovremennyye mediateksty: Problemy identifikatsii, delimitatsii, tipologii [Modern mediatexts: Problems of identification, delimitation, typology]. Medialingvistika, 1 (4), 65-76. [in Russian]

Kecskes, I. (2013). Intercultural pragmatics. Oxford: Oxford University Press.

Konyushkevich, M. I. (2016). Vnutritekstovyye svyazi s predlozhno-soyuznym konnektorom "do togo, chto" $v$ mediatekste [Intratextual connections with prepositional-conjunctional connector "to the point that" in the mediatext]. Medialingvistika, 1 (11), 93-104. [in Russian]

Maliarchuk-Proshina, U. O. (2015). Sintaksicheskiye sredstva vyrazheniya otsenki v mediatekstakh [Syntactic means of expression evaluation in media texts]. Uchenye zapiski Krymskogo federal'nogo universiteta imeni V.I Vernadskogo. Filologiya, 1 (76), 2, 84-94. [in Russian]

Manovich, L. (2001). The language of new media. Cambridge: MIT Press.

Morozova, O. (2017). Monomodal and multimodal instantiations of conceptual metaphors of Brexit. Lege artis. Language yesterday, today, tomorrow. The journal of University of SS Cyril and Methodius in Trnava. Warsaw: De Gruyter Open, II (2), December 2017, 250-283.

Shing, E. (2016). Brexit: Here are the three major winners from a weak pound right now. International business times. Available at: http://www.ibtimes.co.uk/brexit-fallout-rolls-royceglaxosmithkline-experian-are-big-winners-weak-pound-1569154

van Dijk, T. (1977). Text and context. London: Longman.

Veltri, G.A., Redd, R., Mannarini, T. \& Salvatore, S. (2019). The identity of Brexit: A cultural psychology analysis. Journal of applied and community psychology, 29 (1), 18-31.

Vivian, J. (2012). Media of mass communication. Ottawa: Pearson.

Volodina, M. N. (2003). Yazyk SMI kak obyekt mezhdistsiplinarnogo issledovaniya [Language of media as an object of interdisciplinary research]. Moscow: Moscow State University. [in Russian]

Wimmer, R., Dominick, J. (2013). Mass media research. Belmont: Wadsworth Publishing. Wodak, R., Busch, B. (2004). Approaches to media texts. Handbook of media studies. London: Sage Publications, 105-123. 